\title{
School-Based Leadership Perspectives on University Partnerships
}

Excelsior: Leadership in

Teaching and Learning 2021, Vol. 13(3), 232-245

(C) The Author 2021

CC-BY 4.0 International

Reprints and permissions: surface.syr.edu/excelsior https://doi.org/10.14305/in.1

9440413.2021.13.3.04

nyacte.org

\section{(D) Shelley B. Wepner, ${ }^{1}$ Diane W. Gómez, ${ }^{1}$ and Diana Quatroche ${ }^{2}$}

\begin{abstract}
The success of school-university partnerships depends on the leadership. This qualitative study reports on school-based leaders (SBAs) as critical stakeholders in the collaborative process of forming viable partnerships with colleges and universities. It describes SBAs' responsibilities as partners, motivation for forming their partnerships, perceived benefits and challenges of the partnership, perspectives on forming and sustaining a partnership, and self-reflective comments about their leadership characteristics as an SBA and a partner. Sixteen SBAs, most of whom were school principals, responded to 12 interview questions. SBAs indicated that they have been engaged with Professional Development Schools (PDSs) an average of 10 years. They pursued their partnerships with colleges and universities to help their students, teachers, and schools. Even with the additional responsibilities and any challenges encountered, SBAs found that PDSs provided additional resources and support, collaboration, and opportunities to impact future teachers. SBAs believed that they had the necessary leadership qualities for developing PDSs as vehicles for promoting the profession. They saw themselves as collaborative, visionary, dedicated, organized, striving for excellence, motivational, and supportive. Ideas are presented for creating a leadership profile of SBAs involved in PDSs to establish guidelines for their optimum roles and responsibilities in partnership work.
\end{abstract}

Keywords: school-university partnerships, school-based leaders, professional development schools, leadership, sustainability

\footnotetext{
${ }^{1}$ Manhattanville College

2 Indiana State University

Corresponding Author: Shelley B. Wepner, Manhattanville College, 2900 Purchase Street, School of Education Main Office, Benziger Hall, Purchase, NY 10577

Email: shelley.wepner@mville.edu
} 
Clinical partnerships are essential for both $\mathrm{K}-12$ education and teacher preparation. $\mathrm{K}-12$ education needs teacher preparation programs to help with teachers' and leaders' professional development, assist with and enrich student achievement, help with parent engagement, and contribute to a culture of collaboration and shared learning goals. Teacher education needs $\mathrm{K}-12$ education to prepare prospective teachers and leaders, assist faculty with their own professional development, and help with credibility and viability (Wepner, 2014b). These cross-institutional partnerships require sustainable relationships between individuals and groups as they work together for a common cause. These relationships reflect influential leaders who can forge and sustain such relationships.

The depth and breadth of these relationships depend on factors such as accessibility to and availability of partners, leadership interest and capability, teacher buy-in, funding opportunities, and community support. A shared commitment among partners and a willingness to work across institutional settings and cultures are imperative (Byrd \& McIntyre, 2011; Duffield \& Cates, 2008). A key factor for the success of any partnership-whether it exists for a short time period to accomplish a specific task or long periods of time to address multiple pursuits-is both the school-based leadership and the university-based leadership.

School-based administrators (SBAs) include principals, vice principals, department heads, assistant superintendents, superintendents, and others in administrative posts. University-based administrators (UBAs) include department chairs, program coordinators, assistant deans, associate deans, and deans (Stroble \& Luka, 1999). SBAs and UBAs play a pivotal role in the success of school-university partnerships. A better understanding of their leadership perspectives and characteristics could foster the development of successful partnerships.

\section{Role of SBAs as Critical Stakeholders}

This current study focuses on the role of K-12 leaders (or SBAs) as critical stakeholders in the collaborative process of forming viable partnerships with colleges and universities. K-12 leaders hold the keys, both literally and figuratively, to unlocking their schools' classroom doors to college and university students, faculty, and administrators. For partnerships to exist, SBAs must appreciate how their school and district needs can be met; develop policies, procedures, and practices for establishing partnerships; negotiate effectively with colleges and universities; and create systems for evaluating and sustaining partnerships so that they truly are mutually beneficial.

This qualitative study reports on SBAs (e.g., principals, vice principals, department heads, assistant superintendents, superintendents, and others in administrative posts) and their engagement in schooluniversity partnerships. It describes their responsibilities as partners, motivation for forming their partnerships, perceived benefits and challenges of the partnership, perspectives on forming and sustaining a partnership, and self-reflective comments about their leadership characteristics as an SBA and a partner. This study is the second phase of a two-year study. The first phase studied UBAs with a specific type of school-university partnership; a Professional Development School (PDS) (Gómez \& Wepner, 2018). A PDS is a public K-12 school that becomes a partner school with a college or university to prepare teacher candidates, provide faculty development, improve instructional practice, and enhance student learning. PDS partners share responsibilities for professional development and blend their expertise and resources to meet shared goals in a real world setting (Wepner \& Quatroche, 2015).

The purpose of the first phase of this study was to investigate the roles and responsibilities of UBAs 
in relation to their oversight of PDSs. The majority of UBAs in the study were university faculty who spent less than $50 \%$ of their time on PDS work. Findings revealed significant variation in UBA's roles and responsibilities. There was no standardized leadership title, set of responsibilities or qualifications, or structure for the oversight of PDS activities and networks. Three major administrative responsibilities related to PDS work emerged: personnel, programs, and documents. UBAs reported the greatest challenges were time, sustainability, and resources/support (Gómez \& Wepner, 2018). The study of UBAs indicated the importance of additional research on both UBAs and SBAs to determine optimum roles and responsibilities and the necessary characteristics to function as leaders of partnerships. This current study (or second phase) of SBAs contributes to understanding the importance of SBAs with partnership success.

\section{Literature on Partnerships and SBAs}

\section{Benefits of Partnerships}

Numerous reasons exist for pursuing school-university partnerships. Partnerships can raise the level of teacher expectation and student work; increase the student-teacher ratio; expose teachers to new and enhanced methodology; increase teacher leadership; offer innovative and cutting-edge ideas that teachers can use and apply; stimulate collaborative inquiry about practice; cultivate students' improved attitude toward learning; offer new and exciting dialogues about teaching and learning; infuse new blood into the building; and help with teacher renewal (Gilles et al., 2009; Hamel \& Ryken, 2010; Wepner, 2014b). PDSs, especially, have been shown to promote teachers' self-reflection about their instructional and assessment practices; improve student achievement; and provide teacher candidates with the knowledge, skills, and dispositions to enter and remain in the teaching profession (Byrd \& McIntryre, 2011; Castle et al., 2008; McBee \& Moss, 2002; Stroble \& Luka, 1999; Teitel, 1996, 1997, 1998, 1999, 2003; Walker et al., 2008a; Walker et al., 2008b; Wepner, 2014a, b).

\section{Challenges of Partnerships}

There also are challenges to forming partnerships that ought to be acknowledged and addressed. Such challenges include: 1) a paradigm shift, 2) institutional culture clashes, 3) conflicting expectations, 4) communication, and 5) flow of activities from university to K-12 schools (Moreno, 2005; Tomanek, 2005; Wepner et al., 2008).

Paradigm shift. Developing school-university partnerships involves a paradigm shift about who is in charge and what is expected, especially as two different cultures are brought together. Partners act wisely when they bring together four different types of groups-classroom teachers, university faculty, PreK-12 students, and university students - to engage in new types of learning experiences and involve teacher candidates in the classroom to provide assistance to K-12 learners (Epstein \& Sanders, 2006; Wepner \& Hopkins, 2011).

Institutional culture clashes. An institutional culture clash speaks to a set of differing principles by which different groups operate; for example, how one's day is scheduled, how one is compensated for one's work, how one is evaluated for job performance, how one's work environment should be 
managed, and how one defines professional development. Institutional culture clashes are particularly obvious between the K-12 and higher education worlds, especially as PDSs are formed. Classroom teachers are directly involved with their students most of the day. University faculty spend their days differently, with less time interacting with students and more time involved in committee work and scholarship that contributes to their understanding of specific academic disciplines. Their daily pressures are different, creating a different set of expectations for themselves and others. Partners must recognize institutional differences and help their faculty and staff to acknowledge and understand different professional habits and responsibilities (Hovda, 1999; Ledoux \& McHenry, 2008; Wepner et al., 2012; Wepner \& Hopkins, 2011).

Conflicting expectations. Assumptions often are made that both school-based faculty and university faculty want the same thing, but that is often not the case. For example, when university faculty go to a school to work with children, they might expect that the classroom teachers will work alongside them to learn about a specific instructional methodology and assist students with specific tasks. Classroom teachers, on the other hand, might see this as an opportunity to catch up on administrative tasks. Partners ought to be explicit on what they expect from each other when working together in schools and classrooms. Partners also should listen to their staff about realistic expectations (Ledoux \& McHenry, 2008; Strier, 2014; Wepner \& Hopkins, 2011).

Communication. A traditional organizational structure is supplemented with a cross-institutional system to accommodate the additional voices involved in decision-making. It helps when partners are aware of the way communication occurs so that they can do their best to anticipate and stop potential problems (Wepner et al., 2012).

Flow of activities from university to K-12 schools. A major concern from K-12 partners is a oneway flow of activities from the university to classrooms with little reason for teachers to take ownership of a project or to consider using the activities that have been developed by others not directly involved with the curriculum (Tomanek, 2005). In many cases, a school-university partnership is not sustained because there usually is a mismatch between the professional practices of the university faculty and the $\mathrm{K}-12$ teachers, and time has not been devoted to developing a culture of professional learning and improvement. Partners should figure out ways to ensure that university faculty work with K-12 teachers to co-develop projects and programs (Wepner $\&$ Hopkins, 2011) because co-leadership between teachers and university faculty eliminates barriers to success (Mebane, 2000).

\section{SBAs' Leadership on the Benefits of Partnerships}

Given that SBAs are critical for the existence of partnerships, it is helpful to highlight the importance of their leadership in forming, implementing, and sustaining partnerships so that their schools can benefit from such relationships (Bowen, 1995; Bowen \& Adkinson, 1996; Breault, 2014; Bullough et al., 1997; Field, 2008; Stroble \& Luka, 1999; Tilford, 2010; Trachtman \& Levine, 1997). SBAs are responsible for helping their teaching staff to appreciate the value of collaboration within different institutional contexts. They should communicate to their teaching staff ways in which such work contributes to their professional development and helps with their annual reviews. SBAs must be knowledgeable about the potential challenges of forming partnerships yet skillful in convincing their 
teachers to get involved in ways that are mutually beneficial. Even though there are some challenges in bringing two cultures together, as mentioned in the section above, SBAs are in a position to help their teachers and other school stakeholders develop creative approaches for working productively and successfully with their college and university partners.

SBAs, as the leaders who cultivate and sustain partnerships, must ensure the readiness of their schools to partner. Once they do, they usually are the ones who foster relationships with partners. They identify potential partners, prepare for outreach to such partners, and initiate contact with them. These relationships develop in vitality when SBAs help partners to understand the benefits of working with their schools, ensure that their partners are aware of and accept their partnership responsibilities, provide continuous encouragement and recognition to their partners, monitor the partnership's progress, and communicate about such progress to their partners. The SBA's leadership in working closely with their partners and communicating regularly with their school's constituency keeps the partnership concept alive. Active leadership committees or advisory boards and ceremonial events contribute to a partnership's visibility and viability (Wepner \& Gómez, 2020; Wepner \& Hopkins, 2011).

It behooves SBAs to recognize the impact of their actions, and adjust accordingly; in other words, reflect about their leadership qualities. SBAs also must possess a psychological mindset for partnership work. Their willingness to change their usual work patterns, if partnerships are a new responsibility, will give them the time and energy to nurture partners. Critically important is SBAs' wherewithal to balance individual, institutional, community, and societal needs with their own needs (Hovda, 1999; Wepner et al., 2008).

\section{Methodology}

The purpose of this current study was to discover the leadership perspectives of SBAs on schooluniversity partnerships, specifically PDSs. Questions that were addressed included: Who are SBAs? What are their perceived roles and responsibilities as partners? What is their motivation for forming partnerships? What are their perceptions about the benefits and challenges of forming and sustaining partnerships? How do they describe themselves as leaders with partnership work?

\section{Research Protocol}

Invitations were sent to 115 people as possible interviewees about their PDS partnerships. Their names came from a search of school districts and professional organizations focused on school-university partnerships. Most had participated in the 2017 NAPDS (National Association of Professional Development Schools) conference. A scripted email invitation was sent by the researchers from two different universities. The researchers introduced themselves and their role at the university, explained the purpose of the research, and requested responses to 12 semi-structured interview questions, as listed in Figure 1. They explained that it would take approximately 30 minutes of their time and that their responses would be kept confidential. They asked each willing participant to sign a consent form that had been approved by the Institutional Review Board (IRB) of the primary authors' university.

The researchers emailed the questions to those participants who wanted to respond in writing and scheduled telephone interviews with those who preferred to respond verbally. They took notes for all telephone interviews. A grounded theory method was used to analyze the notes from the email 
responses and telephone interviews. The researchers studied participants' responses for each question (\#2 through \#12). They recorded similar terms for each question and then categorized the terms. They then determined themes that emerged across participants (Corbin \& Strauss, 2007; Miles \& Huberman, 1994). For example, with Question \#10 "What makes you as a leader a good partner?", many respondents talked about their willingness to dedicate time to the partnership which became an emergent theme. Additionally, general demographic information about the respondents' actual positions and locations was gathered.

\section{Figure 1}

Questions for interviews of SBAs

We understand that you have a partnership with

1. How long have you had this partnership?

2. Why did you enter into this partnership?

3. What were the challenges to form the partnership?

4. What are the benefits of this partnership?

5. What are the challenges in sustaining this partnership?

6. What are your responsibilities with this partnership?

7. What do you think needs to be in place to form and sustain a partnership?

8. What is it about you as a leader that enabled you to enter into a partnership?

9. If we asked your partner about your leadership style, what would your partner say?

10 . What makes you as a leader a good partner?

11. How would you describe your leadership style?

12. What do you think that you have accomplished as a result of this partnership?

\section{Description of SBAs}

\section{Findings}

A total of 16 SBAs, or $14 \%$, of the 115 invitees, participated in the survey. Twelve participants were female, and four were male. They represented seven states in two geographical regions of the USA; the northeast and the south. Table 1 displays the geographical representation of the respondents. All of the respondents were school administrators, with nine serving as principals, one serving as a vice principal, and one serving as a director of elementary education. Five of the school administrators were PDS administrators at the school or a PDS partnership manager. Eight worked at elementary schools, five worked at secondary schools, and three worked for their entire school district. Table 2 provides a breakdown of the respondents' positions.

\section{Information and Perspectives about Pursuing PDSs}

Sixty-two percent $(n=10)$ of the SBAs reported that their schools or districts have been engaged in PDS work for ten years or less. Thirty-eight percent $(n=6)$ reported that they have been doing PDS work for 11 to 20 years or more. The average number of years for PDS work was 10 years (Question \#1). Table 3 provides the number of years that the schools have been a PDS.

Respondents indicated that they pursued their partnerships to get resources and support for their students, teachers, and schools. Resources included extra hands, cutting-edge technology and research, 
and professional development for their teachers. They also wanted to 1) create a culture of collaboration and reflection to further develop teacher efficacy; 2) have an impact on the development of future teachers; 3) create a hiring pool for their own schools; and 4) have an impact on the field of education in general (Question \#2).

Table 1

Geographical information of respondents

\begin{tabular}{llc}
\hline $\begin{array}{c}\text { Geographic } \\
\text { Regions }\end{array}$ & \multicolumn{1}{c}{ States } & $\begin{array}{c}\text { Number of } \\
\text { Participants }\end{array}$ \\
\hline Northeast & New Jersey & 2 \\
& New York & 2 \\
& Pennsylvania & 2 \\
South & Florida & 1 \\
& Georgia & 2 \\
& South Carolina & 6 \\
& Texas & 1 \\
\hline
\end{tabular}

Table 2

Positions of respondents

\begin{tabular}{lc}
\hline \multicolumn{1}{c}{ Position } & $\begin{array}{c}\text { Number of } \\
\text { Participants }\end{array}$ \\
\hline Director of Elementary Education & 1 \\
Principal & 9 \\
Vice Principal & 1 \\
PDS Administrator (@ school) & 4 \\
PDS Partnerships Manager & 1 \\
\hline
\end{tabular}

The challenges that they encountered in forming their partnerships included organizing and developing roles and responsibilities, communicating and developing trust, and having the necessary funding to launch the partnership (Question \#3). Even with these challenges, respondents indicated three major benefits of their partnerships: 1) additional resources and support; 2) collaboration; and 3) impact on future teachers (Question \#4). The noted benefits were the same as the reasons for pursuing partnerships.

For a partnership to be formed, the SBAs indicated that both the school and the university must have a shared vision and goals with explicit expectations. The school had to have a culture that works well together and teacher buy-in to the idea of having a relationship with a university. The right people had to be part of the partnership, from university professors to the principal and the teachers. There also had to be a communication structure in place that allowed for discussions within and across institutions (Question \#7).

As PDS partners, they were responsible for promoting a vision for the partnership, overseeing the students, serving as the liaison with the university by attending meetings and communicating with the 
UBAs, and engaging in fundraising and grant writing for the PDS. They were the primary persons responsible for all facets of the PDS partnership (Question \#6). They identified four major challenges for sustaining their partnerships: funding, time, communication, and personnel. With personnel, SBAs expressed concerns about the lack of continuity caused by leadership changes at the university level. They also noted that there were difficulties when there were fewer university students in the schools (the extra hands) or the added pressure to spend a good deal of time coaching weak students. They found that PDS work took time away from their other responsibilities and that communication, or lack thereof, with the university interfered with the ability to make continuous progress (Question \#5 and Question \#7). Table 4 provides a list of benefits and challenges that the SBAs identified for pursuing and sustaining PDSs.

\section{Table 3}

Number of years as a Professional Development School

\begin{tabular}{ll}
\hline Years & Number of Professional Development Schools \\
\hline 3 & 1 \\
4 & 1 \\
5 & 1 \\
6 & 4 \\
7 & 2 \\
10 & 1 \\
13 & 1 \\
15 & 1 \\
20 & 2 \\
$>20$ & 2 \\
\hline
\end{tabular}

\section{Perspectives about Leadership with PDSs}

In response to the question about what enabled them as leaders to enter into a partnership (Question \#8), SBAs focused on their beliefs and their leadership characteristics. They shared their beliefs that PDSs help to get the best and brightest teacher candidates in their schools, provide their teachers with professional development, acquire resources for their schools, and assist with K-12 student achievement. They stated that they see themselves as collaborative, visionary, and dedicated.

They indicated that partners would see them as committed to their PDSs and school success, collaborative, transformative, problem-solvers, forward thinking, and innovative. They thought that their partners would view them as able to provide valuable input and function as servant leaders to their teachers and administrative staff (Question \#9).

Respondents believe that they are good partners because they value their status as a PDS to support their teachers, students, and school. They explained that they understand that partnerships are reciprocal relationships that require collaboration; expressed commitment to PDS work and their willingness to dedicate time to its mission; and articulated that they serve as positive role models because they are reflective, current, and focused on validating others (Question \#10).

The description of their leadership style was motivational, supportive, collaborative, visionary, and 
transformational. They described themselves as leaders who strive for excellence and learn while doing. Respondents believe that their leadership style enables them to develop others (Question \#11). Their PDS work has enabled them to have a dynamic environment for all, provide teacher professional development, teacher candidate development, student and family support, and K-12 school improvement (Question \#12). Table 5 provides a list of their beliefs and leadership characteristics.

Table 4

Benefits and challenges for pursuing and sustaining professional development schools

\begin{tabular}{lc}
\hline \multicolumn{1}{c}{ Benefits } & Challenges \\
\hline Additional resources and support & Funding to launch and sustain partnership \\
- Extra hands & Time taken away from other responsibilities \\
Cutting-edge technology and research & Communication \\
Professional development for teachers & - Developing responsibilities \\
- Culture of collaboration and reflection & - Impedes progress when university is \\
$\quad$ within and across partnership. & unresponsive \\
Impact on future teacher development and field & - Developing trust \\
of education & Personnel \\
- Identify pool of future teachers & - Affects continuity because of leadership \\
& changes \\
& - Impacts resource availability with student \\
\end{tabular}

Table 5

School-based administrators'benefits and perceived leadership characteristics

\begin{tabular}{ll}
\hline \multicolumn{1}{c}{ Beliefs } & \multicolumn{1}{c}{ Leadership Characteristics } \\
\hline - Value professional development for teachers, & - Collaborative \\
students, and school support & - Strive for excellence / dedicated \\
- Understand that collaboration and time & - Motivational \\
commitment needed for reciprocal & - Supportive / Servant leader \\
relationships with a university to develop & - Learn while doing / Problem-solver \\
- Appreciate that PDSs create a dynamic & - Visionary / Forward Thinking \\
environment & - Transformational \\
- Truly believe that leadership style is important & - Reflective \\
for partnership to work & - Innovative \\
& - Positive Role Model \\
\hline
\end{tabular}

\section{Discussion}

The SBAs who responded to the survey appear to exemplify entrepreneurial leadership, which is important for steering their schools to new heights. They see PDSs as vehicles for bringing new resources to their schools, offering contemporary and relevant professional development to their teachers, and offering exciting new learning experiences for their $\mathrm{K}-12$ students. These SBAs seem to have used this leadership orientation to go outside their four walls to collaborate creatively and diplomatically with college and university partners to pursue opportunities that are mutually beneficial. 
They have figured out ways to work effectively with their own stakeholders so that they are willing to adjust their normal routines to work with partners. Their apparent knack for tolerating the ambiguity that accompanies partnership work has allowed their PDSs to develop (Wepner \& Gómez, 2020). These leadership attributes are reflected in their own self-described comments about themselves: motivational, supportive, collaborative, striving for excellence, visionary, and transformational.

In addition to their leadership attributes, these SBAs expressed commitment to PDSs which is rooted in their belief that, as leaders, they want to positively affect the profession and have an impact on the quality of future teachers (Tilford, 2010; Wepner, 2014b). They are willing to tolerate the messiness of working across institutions and accept and leverage failure in order to grow something that benefits a wider net of stakeholders (Wepner \& Gómez, 2020). As Mastroianni (2018) indicated, these SBAs appreciate the importance of creating an environment that integrates teacher candidates into their schools because it not only helps these candidates grow into teachers but also enriches the school's culture. Their willingness to share with colleges and universities the responsibility of preparing teacher candidates strengthens current teachers' knowledge and skills, which is a critical component of PDSs (Bullough et al., 1997; Wepner \& Gómez, 2020).

However, as with UBAs from the first study, these SBAs cited challenges for sustaining PDSs: time, funding/resources, and changes in leadership/personnel. They also expressed administrative challenges; having the right communication structures in place; and assigning roles and responsibilities for partners and themselves. These additional concerns could be a function of the difference between K-12 administrators, who by the nature of their jobs are focused on policies and procedures, and higher education faculty (as seen from the UBAs in the first study), who do not have to be as attentive to strictures and structures. Moreover, unlike UBAs, SBAs have to open up their schools to partners (Gómez \& Wepner, 2018; Stroble \& Luka, 1999).

Notwithstanding these challenges and concerns, these SBAs indicated that they were open and motivated to participate in partnership work. They believe that their vision has contributed to their ability to succeed in forming and sustaining their schools as PDSs (Wepner \& Gómez, 2020). Their responses support Tilford's (2010) assertions about the leadership attributes needed to participate in PDS work. He found that principals who willingly embrace PDS work see connections between PDS goals and their other leadership work. These principals are willing to change enough to integrate PDS work into the culture of their schools. They are especially committed to PDS work when it involves inquiry into K-12 student learning yet are motivated to participate in PDS work for other reasons as well. They want to create a new school culture.

Strong principal leadership is a critical ingredient for the formation of PDSs (Bowen, 1995; Bowen \& Adkinson, 1996; Field, 2008; Tilford, 2010). The SBAs' descriptions of themselves highlight their perceived leadership qualities. They expressed that they "learn while doing," and believe that they are positive role models. Their willingness to work with partners across institutional settings supports the literature on the necessary leadership characteristics for developing and sustaining partnerships (Byrd \& McIntrye, 2011; Duffield \& Cates, 2008). These SBAs are committed to and enthusiastic about PDSs because of the perceived benefits (Bullough et al., 1999; Castle et al., 2008; McBee \& Moss, 2002; Wepner \& Gómez, 2020).

Their belief in the value of PDSs seems to have enabled them to be collaborative and respectful partners and, at the same time, positive role models and encouraging mentors for their own teaching and administrative staff. Their entrepreneurial spirit for seeing and seizing opportunities seems to help them to be open to make right turns and wrong turns and learn more about the right direction as they go (Schlesinger et al., 2012). They appear to have allowed opportunities to emerge with their partnerships 
(e.g., collaborative research to inform future practices and new technologies to support innovations) (Sarasvathy, n.d.; Wepner \& Gómez, 2020). They also seem to appreciate that their PDSs are about people and relationships (Sanderlin, 2018), and are patient with the process of establishing a shared vision between their partners (Sheninger, 2010). These leadership characteristics have contributed to their success to date.

This study's sample size limits the ability to generalize about SBAs' perspectives on PDSs and their leadership characteristics. One reason for this limited sample size could be the request to school administrators, already busy with administrative oversight of their schools, to spend time on responding to the survey's questions. An expanded pool of respondents would contribute to an in depth understanding of the roles, responsibilities, and challenges of SBAs. A more comprehensive leadership profile of SBAs involved in PDS work could be used to establish guidelines and eventually standards for the optimum roles and responsibilities of SBAs to help PDSs to continue to endure.

\section{Conclusions}

SBAs are the pivotal persons for working with and connecting stakeholders, sustaining relationships, and maintaining and promoting PDS growth. Their leadership determines a partnership's success. They must have the knowledge, skills, and dispositions to negotiate two cultures: their own schools' culture and the university partners' culture. Their role is to navigate the challenges of cross-institutional partnerships as diplomatically as possible and work assiduously to keep all stakeholders committed to the partnership.

SBAs also are responsible for executing partnership agreements, monitoring budgets, working effectively with personnel, and ensuring that initiatives are appropriate, functioning, and well-funded. Leadership preparation programs ought to consider the idea of screening for those who have the aforementioned technical skills and the leadership skills to motivate, influence, and lead people in the right direction. As such, leadership candidates should communicate and demonstrate their beliefs in the benefits of forming PDSs.

In addition to tapping into recent NAPDS conferences, it would be useful to reach out to statewide education departments that require school-university partnerships such as the state of Maryland and search for universities that have sustained their PDSs for five years or more. These organizations and institutions could provide contact information for SBAs who are engaged with PDS work. Personal contacts with colleagues at other higher education institutions with long-term partnerships also can lead to willing SBAs to participate in the survey. To help learn more about SBAs' school demographics, questions should be included to seek information about, for example, the size and grade levels of the K12 schools, the types of communities in which the schools reside, and the racial/ethnic composition.

Efforts should be made with SBAs to encourage increased partnership work by helping them to appreciate ways in which partnerships add new dimensions to their schools and districts that ultimately enhance their students' learning experiences. Their willingness to take the leap and do the extra work will create pathways to enriching and exciting opportunities. Part of this effort might require additional research on the kind of leadership preparation and screening that is needed to promote principals' inclination and qualifications for leading PDSs (Tilford, 2010).

In addition to ensuring that SBAs have the necessary leadership characteristics, it is important for proponents of PDSs to formulate for local, regional, and statewide policy makers, politicians, and legislators a strong rationale for SBAs' engagement in partnerships with colleges and universities. SBAs' 
development of their schools as PDSs will help to improve the education enterprise with respect to teacher and leader development, K-12 student learning, parent engagement, faculty development, and teacher candidate preparation. This study is an important step in understanding the leadership perspectives and characteristics of SBAs who have been successful in developing and sustaining partnerships.

\section{Declaration of Conflicting Interests}

The author declared no potential conflicts of interest with respect to the research, authorship, and/or publication of this article.

\section{Funding}

The authors received no financial support for this research.

\section{ORCID iD}

Shelley B. Wepner (iD https://orcid.org/0000-0003-2731-4192

\section{References}

Bowen, G. (1995, August). The role of the principal in the professional development school [Conference session]. Annual Meeting of the National Council of Professors of Educational Administration, Williamsburg, VA, United States. http://files.eric.ed.gov/fulltext/ED401639.pdf

Bowen, G., \& Adkinson, J. (1996). Institutionalizing professional development schools: Supporting the principal. (ED409623). ERIC. http://eric.ed.gov/?q=ED409623\&id=ED409623

Breault, R. (2014). Power and perspective: The discourse of professional development school literature. Asia Pacific Journal of Teacher Education, 42(1), 22-35. https://doi.org/10.1080/1359866X.2013.869547

Bullough, R., Kauchak, D., Crow, N., Hobbs, S., \& Stokes, D. (1997). Professional development schools: Catalysts for teacher and school change. Teaching and Teacher Education, 13(2), 153-169. https://doi.org/10.1016/s0742-051x(96)00017-0

Byrd, D., \& McIntryre, D. (2011). Types of partnerships. In S. Wepner and D. Hopkins (Eds.), Collaborative leadership in action: Partnering for success in schools (pp. 27-48). Teachers College Press.

Castle, S., Rockwood, K., \& Tortora, M. (2008). Tracking professional development and student learning in a professional development school partnership. School-University Partnerships, 2(1), 47-60.

Corbin, J., \& Strauss, A. (2007). Basics of qualitative research: Techniques and procedures for developing grounded theory. Sage.

Duffield, J., \& Cates, W. (2008). Establishing and maintaining professional development schools: A Delphi study. School-University Partnerships, 2(2), 27-50.

Epstein, J., \& Sanders, M. (2006). Prospects for change: Preparing educators for school, family, and community partnerships. Peabody Journal of Education, 81(2), 81-120. https://doi.org/10.1207/s15327930pje8102_ 5 
Field, S. (2008). How highly effective professional development school principals utilize researchbased leadership practices to lead the school-university partnership (Publication No. AAT 3312857) [Doctoral dissertation, University of Colorado Denver]. ProQuest Dissertations Publishing.

Gilles, C., Wilson, J., \& Elias, M. (2009). School-university partnership: Perceptions of the teachers. School-University Partnerships, 3(1), 100-112.

Gómez, D., \& Wepner, S. (2018). University leadership of professional development schools. Excelsior: Leadership in Teaching and Learning, 11(1), 18-30. https://doi.org/10.14305/in.19440413.2018.11.1.02

Hamel, F., \& Ryken, A. (2010). Rehearsing professional roles in community: Teacher identity development in a school-university partnership. Teacher Development, 14(3), 335-350. https://doi.org/10.1080/13664530.2010.504015

Hovda, R. (1999). Working on a public-school calendar: Personal reflections on the changing role of university faculty member in a professional development school. Peabody Journal of Education, 74(3-4), 85-94. https://doi.org/10.1080/0161956x.1999.9695374

Ledoux, M., \& McHenry, N. (2008). Pitfalls of school-university partnerships. The Clearing House: $A$ Journal of Educational Strategies, Issues and Ideas, 81(4), 155-160. https://doi.org/10.3200/tchs.81.4.155-160.

Mastroianni, S. (2018, November 14). Principal's perspective on impact of PDS on faculty and students[Virtual presentation]. Manhattanville College, Purchase, NY, United States.

McBee, R., \& Moss, J. (2002). PDS partnerships come of age. Educational Leadership, 59(6), 61-64.

Mebane, D. (2000). Responses of first-year participants in a middle school professional development schools partnerships. The Journal of Educational Research, 93(5), 287-293. https://doi.org/10.1080/00220670009598720

Miles, M., \& Huberman, A. (1994). Qualitative data analysis. Sage.

Moreno, N. (2005, Spring). Science education partnerships. Being realistic about meeting expectations. Cell Biology Education, 4(1), 30-32. https://doi.org/10.1187/cbe.04-11-0050

Sanderlin, J. (2018, July 10). Why not? How to build innovative community partnerships. https://edublog.scholastic.com/post/why-not-how-build-innovative-community-partnerships

Sarasvathy, S. (n.d.) What makes entrepreneurs entrepreneurial? https://www.effectuation.org/sites/default/files/research papers/what-makes-entrepreneursentrepreneurial-sarasvathy $0 . p d f$

Schlesinger, L.., Kiefer, C., \& Brown, P. (2012, March). New project? Don't analyze-act. Harvard Business Review. https://hbr.org/2012/03/new-project-dont-analyze-act

Sheninger, E. (2010, June 10). A principal's reflections: Reflections on teaching, learning, and leadership. https://esheninger.blogspot.com/2010/06/tips-forestablishing-meaningful.html.

Strier, R. (2014). Fields of paradox: University-community partnerships. Higher Education, 68(2), 155-165. https://doi.org/10.1007/s10734-013-9698-5

Stroble, B., \& Luka, H. (1999). It's my life now: The impact of professional development school partnerships on university and school administrators. Peabody Journal of Education, 74(3-4), 123-135. https://doi.org/10.1207/s15327930pje7403\&4 10

Teitel, L. (1996). Getting down to cases. Contemporary Education, 67(4), 200-205.

Teitel, L. (1997). Changing teacher education through professional development school partnerships: A five-year follow-up study. Teachers College Record, 99(2), 311-334. 
Teitel, L. (1998). Governance: Developing professional development school governance structures. American Association for Colleges of Teacher Education.

Teitel, L. (1999). Looking toward the future by understanding the past: The historical context of professional development schools. Peabody Journal of Education, 74(3-4), 6-20. https://doi.org/10.1207/s15327930pje7403\&4 1

Teitel, L. (2003). The professional development school handbook: Starting, sustaining, and assessing partnerships that improve student learning. Corwin.

Tilford, K. (2010). A phenomenological study of professional development schools: How principals make sense of their role. School-University Partnerships, 4(2), 60-73.

Tomanek, D. (2005, Spring). Building successful partnerships between P-12 and universities. Cell Biology Education, 4(1), 28-29. https://doi.org/10.1187/cbe.04-11-0051

Trachtman, R., \& Levine, M. (1997). Reinventing leadership in professional development schools. In R.

Trachtman and M. Levine (Eds.), Making professional development schools work: Politics, practice, and policy (pp. 76-87). Teachers College Press.

Walker, D., Sorensen, C., Smaldino, S., \& Downey, P. (2008). A model for a professional development school intervention: Real findings. School-University Partnerships, 2(1), 6-26.

Walker, C., Zeek, C.., Foote, M., \& Naizer, G. (2008). Re-creating teacher education through long-term partnerships. In I. Guadarrama, J. Ramsey, and J. Nath (Eds.), University and school connections: Research studies in professional development schools (pp. 203-220). Information Age.

Wepner, S. (2014a). Developing partnerships through collaboration to promote professional development. In S. Kragler, L. Martin, K. Bauserman, and D. Quatroche (Eds.), The handbook of professional development, $P K$-12: Successful models and practice(pp. 339-358). Guilford.

Wepner, S. (2014b). The role of leadership in the PDS. In J. Ferrara (Ed.), Professional development schools: Creative solutions for educators (pp. 121-128). Rowman \& Littlefield.

Wepner, S., Bettica, A., Gangi, J., Reilly, M., \& Klemm, T. (2008). Using a crosscurricular learning experience to promote student engagement through a school-college collaboration. Excelsior: Leadership in Teaching and Learning, 3(1), 27-45.

Wepner, S., Ferrara, J., Rainville, K., Gómez, D., Lang, D., \& Bigaouette, L. (2012). Changing suburbs, changing students: Helping school leaders face the challenges. Corwin.

Wepner, S., \& Gómez, D. (2020). Entrepreneurial leadership: Strategies for creating and sustaining partnerships for $K-12$ schools. Rowman \& Littlefield.

Wepner, S., and Hopkins, D. (Eds.). (2011). Collaborative leadership in action: Partnering for success in schools. Teachers College Press.

Wepner, S., \& Quatroche, D. (2015, February). Teacher candidate growth in professional development schools: Where's the proof?[Roundtable presentation]. Annual Meeting of the American Association of Teacher Education. Atlanta, GA, United States. 